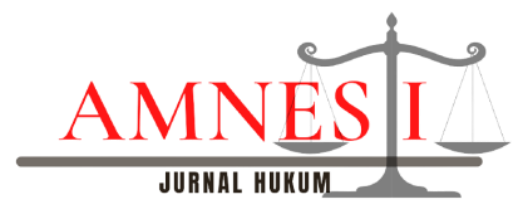

Amnesti: Jurnal Hukum

Vol. 3 No. 1 (2021) pp. 53-59

p-ISSN: 2656-3029 | e-ISSN: 2775 - 0604

\title{
The Roles of Local Governments in Accommodating the Registration of SME's Product Trademarks
}

\author{
Muhammad Bagus Boy Saputra ${ }^{1}$, Heniyatun ${ }^{2}$, Chrisna Bagus Edhita Praja ${ }^{3 *}$, \\ Hary Abdul Hakim ${ }^{4}$ \\ 1,2,3,4 Universitas Muhammadiyah Magelang, Magelang, Indonesia \\ *e-mail: chrisnabagus@ummgl.ac.id
}

DOI : https://doi.org/10.37729/amnesti.v3i1.1227

Submitted: November 2021 Revised: Januari 2021 Accepted: Januari 2021

\begin{tabular}{|c|c|}
\hline & ABSTRACT \\
\hline $\begin{array}{l}\text { Keywords: } \\
\text { Role of } \\
\text { Government, } \\
\text { Trademark } \\
\text { Registration, } \\
\text { MSME }\end{array}$ & $\begin{array}{l}\text { One of the manifestations of the government's alignment with the } \\
\text { protection and development of MSMEs is the issuance of Law } \\
\text { Number } 20 \text { of } 2008 \text { concerning Micro, Small and Medium Enterprises } \\
\text { (UU MSMEs). Protection of MSME products is protection for } \\
\text { products consisting of goods and/or services. Every product, both } \\
\text { goods and services, has material and immaterial wealth. Intellectual } \\
\text { Property Rights (IPR), especially trademarks, are immaterial wealth } \\
\text { for MSME products that need legal protection. This study aims to } \\
\text { analyze the role of the Kebumen district government in } \\
\text { accommodating the registration of MSME product brands. This } \\
\text { study uses a normative juridical method with a qualitative approach. } \\
\text { The legal materials used in this study include primary and secondary } \\
\text { legal materials. Primary legal materials are Law Number } 20 \text { of } 2016 \\
\text { concerning Marks and Geographical Indications, Regulation of the } \\
\text { Regent of Kebumen Number } 71 \text { of 2016 concerning Position, } \\
\text { Organizational Structure, Duties and Functions, as well as Work } \\
\text { Procedures for the Department of Manpower and Cooperatives, } \\
\text { MSME (MSME Kebumen Regent Regulation). Secondary legal } \\
\text { materials are journaled articles, law books and websites. The results } \\
\text { of the study indicate the role of the Kebumen Regency Government } \\
\text { in accommodating trademark registration on MSME products in } \\
\text { Kebumen Regency through the KUMKM Service and the KUMKM } \\
\text { Integrated Business Service Center (PLUT). Activities carried out are } \\
\text { in the form of socialization, consulting services, training, and }\end{array}$ \\
\hline
\end{tabular}


assistance for MSMEs in trademark registration at the DJKI to protect the law and develop MSMEs.

\begin{tabular}{|c|c|}
\hline & ABSTRAK \\
\hline $\begin{array}{l}\text { Kata Kunci: } \\
\text { Peran } \\
\text { Pemerintah, } \\
\text { Pendaftaran } \\
\text { Merek, UMKM }\end{array}$ & $\begin{array}{l}\text { Salah satu wujud keselarasan pemerintah dalam perlindungan dan } \\
\text { pengembangan UMKM adalah dengan diterbitkannya Undang-Undang } \\
\text { Nomor } 20 \text { Tahun } 2008 \text { tentang Usaha Mikro, Kecil dan Menengah (UU } \\
\text { UMKM). Perlindungan produk UMKM adalah perlindungan terhadap } \\
\text { produk yang terdiri dari barang dan/atau jasa. Setiap produk, baik barang } \\
\text { maupun jasa, memiliki kekayaan material dan immaterial. Hak atas } \\
\text { Kekayaan Intelektual (HKI), khususnya merek, merupakan kekayaan } \\
\text { immaterial bagi produk UMKM yang memerlukan perlindungan hukum. } \\
\text { Penelitian ini bertujuan untuk menganalisis peran pemerintah kabupaten } \\
\text { Kebumen dalam mengakomodasi pendaftaran merek produk UMKM. } \\
\text { Penelitian ini menggunakan metode yuridis normatif dengan pendekatan } \\
\text { kualitatif. Bahan hukum yang digunakan dalam penelitian ini meliputi } \\
\text { bahan hukum primer dan bahan hukum sekunder. Bahan hukum primer } \\
\text { adalah Undang-Undang Nomor } 20 \text { Tahun } 2016 \text { tentang Merek dan } \\
\text { Indikasi Geografis, Peraturan Bupati Kebumen Nomor } 71 \text { Tahun } 2016 \\
\text { tentang Kedudukan, Susunan Organisasi, Tugas dan Fungsi, serta Tata } \\
\text { Kerja Dinas Tenaga Kerja dan Koperasi, UMKM ( Peraturan Bupati } \\
\text { Kebumen UMKM). Bahan hukum sekunder adalah artikel jurnal, buku } \\
\text { hukum dan website. Hasil penelitian menunjukkan peran Pemerintah } \\
\text { Kabupaten Kebumen dalam mengakomodir pendaftaran merek pada produk } \\
\text { UMKM di Kabupaten Kebumen melalui Layanan KUMKM dan Pusat } \\
\text { Layanan Usaha Terpadu (PLUT) KUMKM. Kegiatan yang dilakukan } \\
\text { berupa sosialisasi, jasa konsultasi, pelatihan, dan pendampingan bagi } \\
\text { UMKM dalam pendaftaran merek di DJKI untuk mengayomi hukum dan } \\
\text { mengembangkan UMKM.. }\end{array}$ \\
\hline
\end{tabular}

\section{INTRODUCTION}

Micro, Small, and Medium Enterprises (MSMEs) are productive economic enterprises born as human life activities fulfilling their daily needs. Economic needs provide goods and services for consumers and build regional economic growth, while socially, among others, in the absorption of labour and efforts to reduce poverty (Warsilan \& Noor, 2015). Thus, MSMEs need to get opportunity, support, legal aid, and the development of broad advantages as government alignment that impacts the economic development in society (Fuati \& Indrawati, 2020).

One of the proofs of the government's alignment with the protection and development of MSMEs is the enactment of Law Number 20 of 2008 on Micro, 
Small and Medium Enterprises (MSMEs Law). The Protection of MSME products consists of goods and services (Betlehn \& Samosir, 2018). Every product, both goods and services, has material and immaterial property. Material is the material property, while immaterial wealth is the intangible property of a product part of Intellectual Property Rights (IPR).

According to Sihombing, IPR has a positive impact on the sustainability of MSMEs (Sihombing, 2018), namely:

1. As a business asset

2. As support of business development

3. As legal protection and preventing fraudulent competition

4. As guidance of innovation and creativity

5. As an image-building

Trademark is a part of IPR related to the protection of immaterial property (Nasution, 2020). A trademark is a sign given by producers to the goods and services they produce to differentiate them from other similar products (Sulastri $\& W, 2018)$.

The current trademark protection is based on Law Number 20 of 2016 on Trademarks and Geographical Indications (in the future abbreviated as TGI Law). TGI Law defines as a marked sign that can be displayed graphically in the form of an image, logo, name, word, letter, number, colour arrangement in two or three dimensions, sound, hologram, or a combination of two or more elements to distinguish goods and/or services produced by persons or legal entities in the activities of trading goods and/or services (Heniyatun, Sulistyaningsih, Iswanto, Asiyah, \& Praja, 2020).

MSMEs in the Kebumen district are one of the pillars of the community's economy. It is because the local government of Kebumen district through the Department of Manpower, Cooperatives, MSMEs and Medium and the Center for Integrated Business Services for Cooperatives, Micro, Small and Medium Enterprises (PLUT-KUMKM) continues to strive to guide MSME actors to develop their business (Indrawati \& Amnesty, 2019). One of these efforts is to accommodate trademark registration on MSME products in the Kebumen district. For this reason, this study aims to clarify the role of the Kebumen Regency Government in accommodating trademark registration. 


\section{RESEARCH METHODS}

This research method is normative legal research. Normative legal research is legal research conducted by examining library materials to find legal rules, legal principles and legal doctrines to answer legal problems (Marzuki, 2017). This study uses a statute approach. The sources of legal materials for this research are primary legal materials and secondary legal materials. The collection of legal materials is carried out using a literature study. Analysis of legal materials using qualitative methods. The legal materials in this study are presented in narrative texts, which are arranged systematically.

\section{RESULTS AND DISCUSSION}

In Indonesia, the government holds an important role in the sustainability of MSMEs, like trademark registration on MSME products (Sarfiah, Atmaja, \& Verawati, 2019). Kebumen Regency government obligate to accommodate the trademark registration on MSME products in their Regency. The legal basis mentioned in Kebumen Regent Regulation Number 71 of 2016 con Position, Organizational Structure, Duties and Functions, and Work Procedures for the Department of Manpower and Cooperatives, MSME (MSME Kebumen Regent Regulation). This role is carried out by the government through the Micro, Small and Medium Enterprises Cooperative Service/Koperasi Usaha Mikro Kecil dan Menengah (KUMKM) and Integrated Business Service Center/ Pusat Layanan Usaha Terpadu (PLUT) KUMKM.

The MSME actors allow consulting directly with the MSME assistant consultant for the production section at the KUMKM and PLUT KUMKM Offices (Indrawati \& Setiawan, 2020). The MSME actors will explain all matters relating to trademark registration at the Indonesian Directorate General of Intellectual Property (DGIP). In addition, the accompanying consultant will also explain the importance of trademark registration, legal protection of trademarks and even trademark licenses. Consultants also provide consultancy services by directly visiting business actors at their place of business so that consultants can understand various things that occur in the business activities of these business actors.

MSME actors who agree to register their trademark then collect various trademark registration files to the KUMKM Office. The application for registration of the mark is then checked for completeness by officers at the 
KUMKM Service. The completed file is then submitted for registration at the DJKI. Various matters relating to trademark registration will be carried out between DJKI and the KUMKM Service, then the KUMKM Service will convey it to the relevant business actor. The KUMKM Office, in this case, functions as a facilitator between DJKI and business actors.

The existence of PLUT KUMKM as a consultant accompanying MSMEs and the KUMKM Office as a facilitator for trademark registration at DGIP certainly provides many benefits for MSME actors in the Kebumen district. This consulting service is expected to provide explanations and understanding of MSME actors regarding trademark registration and the importance of legal protection of trademarks.

The KUMKM Office as a facilitator of trademark registration applications to the DGIP, is also beneficial for MSME actors. However, the existence of the KUMKM Office as a facilitator will make it easier for MSME actors to register their trademarks rather than to pursue the registration in the central Office in Jakarta.

The MSME actor will get free services for applying trademark registration facilities by PLUT KUMKM and the KUMKM Office of Kebumen Regency. This type of government assistance for the MSME actors to get legal protection in preventing disputes over trademark abuse by other parties (Atmoko, 2019). Furthermore, the protection of the trademarks is also expected to maintain business continuity, increase product sales, and support the regional economy of Kebumen Regency.

In essence, the government of Kebumen Regency, through the related Office, has tried its best to provide services regarding trademark registration. Otherwise, this effort faces various disadvantages. It can be observed from the total of 99 products. There only six trademark's product registered. Based on interviews conducted with PLUT KUMKM, the obstacle faced was the lack of awareness of MSME actors in registering their trademarks. This situation because MSME actors' believe that the advantages achieved are not comparable to the efforts made. In addition, the perception that the IPR system is esoteric, too complicated and time-consuming is also an obstacle in the implementation of trademark registration.

The above can be used as a benchmark regarding the role of the government in accommodating trademark registrations on MSME products in the Kebumen district. The government has not played a leading role, even 
though the government has been very helpful for the community in registering their trademarks.

\section{CONCLUSION}

The role of the Kebumen Regency Government in accommodating trademark registrations on MSME products in Kebumen Regency is based on the MSME Kebumen Regent Regulation. The government carries out these roles through the KUMKM Service and PLUT KUMKM. Its activities provide socialization, consulting services, training, and mentoring MSMEs in trademark registration at the DGIP to protect the law develop MSMEs. The obstacle faced is the lack of awareness of MSME actors in registering their trademarks. This situation because MSME actors' believe that the advantages achieved are not comparable to the efforts made.

\section{BIBLIOGRAPHY}

Atmoko, D. (2019). Perlindungan Hukum terhadap Pemegang Hak Merek Menurut Undang-Undang Nomor 20 Tahun 2016 tentang Merek dan Indikasi Geografis. Jurnal Hukum Sasana, 5(2), 75-86.

Betlehn, A., \& Samosir, P. O. (2018). Upaya Perlindungan Hukum Terhadap Merek Industri Umkm Di Indonesia. Law and Justice, 3(1), 1-11. https://doi.org/10.23917/laj.v3i1.6080

Fuati, S. C., \& Indrawati, S. (2020). Model Penyelesaian Wanprestasi Dalam Kredit Mikro Pada BKK Cabang Kemiri Kabupaten Purworejo. Amnesti:Jurnal Hukum, 2(2), 1.

Heniyatun, Sulistyaningsih, P., Iswanto, B. T., Asiyah, Y., \& Praja, C. B. E. (2020). Kajian Yuridis Perlindungan Merek Terhadap Gugatan Merek Nama Orang Terkenal. Borobudur Law Review, 2(2), 137-149.

Indrawati, S., \& Amnesti, S. K. W. (2019). Perlindungan Hukum Merek Pada Produk Usaha Kecil di Kabupaten Kebumen. Amnesti: Jurnal Hukum, 1(1), 29. Indrawati, S., \& Setiawan, B. (2020). Penyuluhan Kesadaran Hukum Perlindungan Produk UMKM di Kabupaten Kebumen Melalui Pendaftaran Merek. Surya Abdimas, 4(September), 37-43.

Marzuki, P. M. (2017). Penelitian Hukum. Jakarta: Kencana Prenada Media Gruop. Nasution, L. (2020). Efektifitas HKI Sebagai Pelindung Industri Kreatif dan UMKM di Tengah Pandemi Covid-19. ADALAH Buletin Hukum E Keadilan, volume 4(1), 238-250.

Sarfiah, S., Atmaja, H., \& Verawati, D. (2019). UMKM Sebagai Pilar Membangun Ekonomi Bangsa. Jurnal REP (Riset Ekonomi Pembangunan), 4(2), 137-146. https://doi.org/10.31002/rep.v4i2.1952 
Sihombing, E. N. (2018). Kebijakan Afirmatif Bagi Usaha Mikro, Kecil Dan Menengah Di Bidang Kekayaan Intelektual. Jurnal Rechts Vinding: Media $\begin{array}{llll}\text { Pembinaan Hukum Nasional, } & \text { 7(3), }\end{array}$ https://doi.org/10.33331/rechtsvinding.v7i3.273

Sulastri, \& W, Y. Y. (2018). Perlindungan Hukum terhadap Merek (Tinjauan terhadap Merek Dagang Tupperware Versus Tulipware). Yuridis, 5(1), 160172.

Warsilan, W., \& Noor, A. (2015). Peranan Infrastruktur terhadap Pertumbuhan Ekonomi dan Implikasi pada Kebijakan Pembangunan di Kota Samarinda. MIMBAR, Jurnal Sosial Dan Pembangunan, 31(2), 359. https://doi.org/10.29313/mimbar.v31i2.1444 